\title{
A Proliferation-inducing Ligand (APRIL) Acts as an Angiogenic Factor by Inducing Vascular Endothelial Growth Factor (VEGF)
}

\author{
Mina Song and Sayeon Cho \\ College of Phamacy, Chng-Ang Lniversity, Seoul 156-756, Korea. "E-mail: șchoacauackr \\ Received September 1, 2008
}

Key Words : APRIL. Angiogenesis. Vascular endothelial growth factor (VEGF)

\begin{abstract}
Angiogenesis, the generation of new capillary blood vessels from pre-existing vessels. occurs under normal and pathological conditions. Although angiogenesis in physiological processes is tightly regulated by a balance of stumulatory factors and uhibitory factors, disrupted balance effect plays a leading role in the progress of diseases such as tumor growth. rheumatoid arthritis and various blood vesselrelated pathology. ${ }^{1 \cdot \hat{3}}$ Tunor growth relies on angiogenesis to recelve an adequate supply of nutnents and oxygen. In addition. the newly formed blood vessels provide a way for tumor cells to enter the circulation and to metastasize to distant organs. Therefore. treatment of cancer with antiangiogenic agents will control cancer cell growth and metastasis. Among a variety of angiogenic factors, VEGF and basic fibroblast growth factor (bFGF) have a prominent activity in tumor metastasis and mortality. ${ }^{+}$Specially. VEGF expression is induced in various cancer by stumuli including hypoxia. activation of IGF-IR. or $\mathrm{p} 53$ loss of function and transcriptional activation of VEGF gene is mediated by hypoxia-inducible factor-1 (HIF-1) $)^{5.6}$ or nuclear factorkappa $\mathrm{B}(\mathrm{NF}-\mathrm{KB}){ }^{?}$
\end{abstract}

Members of the TNF cytokine family are critically implicated in various biological responses. mcluding unfections. inflanmiation, autoummule diseases. and tissue homeostasis. ${ }^{8.9}$ APRIL, a new member of the TNF family, is abundantly expressed in many tumor cells and tissues. ${ }^{1(1-12}$ APRIL has been known to stmulate tumor cell and leukemia cell growth. ${ }^{15.13 .14}$ regulate tumor cell apoptosis, ${ }^{11.15}$ or activate NF- $\kappa B{ }^{16,17}$ However, the function of APRIL in tumor cells is not yet clear.

Since anglogenesis process is composed of various steps including endothelial cell migration through extracellular matrix, we investigated the effect of APRIL on endothelial cell migration. HEK 293 cells were transfected with APRIL expression plasmid and then transfected cells were selected as described in experimental section. After confinmation of protein expression of APRIL (Fig. IA). conditioned medium (CM) from the selected cells was obtained. In a chemotaxis chamber. human unbilical vein endothelial cells (HUVECs) were treated with $\mathrm{CM}$ from stably transfected cells for $2 \mathrm{~h}$ and HUVECs that had been migrated through menibrane pores were counted under microscope. $\mathrm{CM}$ derived from stable APRIL-transfected cells (APRIL-CM) showed significantly induced migratory effect. compared to that of controlCM (Fig. 1B). Thus, this result suggests that APRIL-CM has the biological activity that can induce endothelial cell migration.

We next examined the ability of APRIL-CM to promote the mesh-like structures of HUVECs on matrigel. Matrigel is generally used for studying HUVEC attachment, migration and differentiation. The extent of mesh-like structure was more enhanced in HUVECs influenced in APRIL-CM than that of control CM (Fig. 2A and B). These data present that APRIL-CM has angiogenic activity involved in migration and tube formation of endothelial cells.

We then measured the protein level of VEGF in APRILCM to investigate whether VEGF production is involved in APRIL-stimulated HUVEC tube formation because it is a major component of angiogenesis. Using ELISA assay kit. we found that APRIL-overexpressing cells released significantly more VEGF than control cells (Fig. 3). This result suggests that the increased secretion of VEGF is associated with APRIL-induced angiogenic activity involved in migration and tube formation.

We next carried out luciferase reporter assay to examine whether APRIL regulates the transcriptional activity of NF-
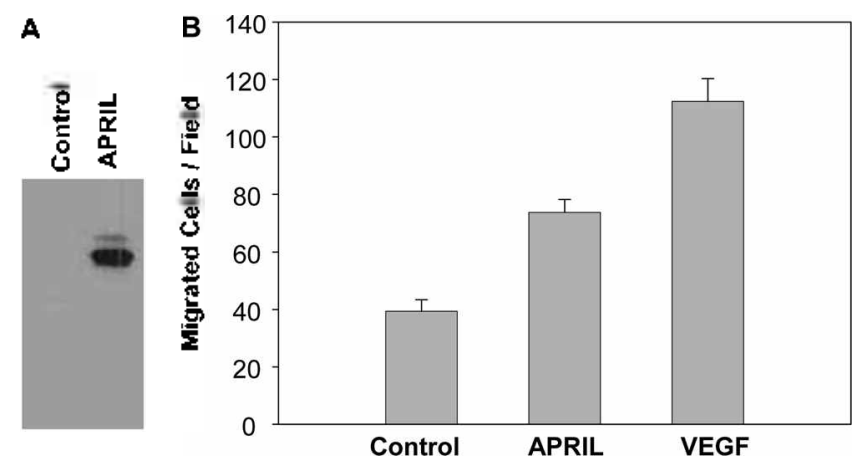

Figure 1. APRIL expression in stably transfected HEK 293 cells and HUVEC migration assays. (A) Stably transfected cells were lysed in a butter solution, followed by centrifugation at $13,000 \mathrm{rpm}$ for $30 \mathrm{~min}$. Cell lysates were run in SDS-PAGE and transfermed to nitrocellulose membrane. The blocked membrane was then incubated with an anti-HA antibody, followed by an appropriate secondary antibody conjugated to horseradish peroxidase. The immunoreactive bands were visualized using an ECL system. (B) APRIL-CM stimulates endothelial cell migration. Migration assays with HUVECs were carried out in 48-well microchemotaxis chambers. HUVEC's were incubated with control-CM or APRIL$\mathrm{CM}$ for $2 \mathrm{~h}$. Atter fixation and staining, the number of migrated cells was detemined by counting two regions of each well under a microscope. VEGF $(20 \mathrm{ng} / \mathrm{mL})$ was used as a positive control. 


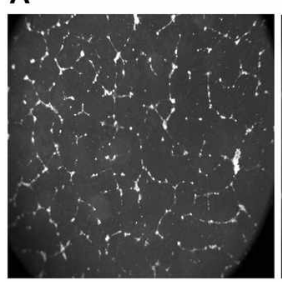

Control

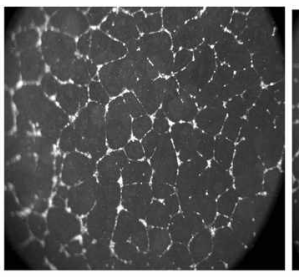

APRIL

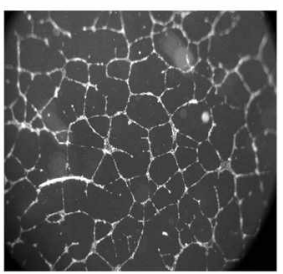

bFGF (10 $\mathrm{ng} / \mathrm{ml})$
B

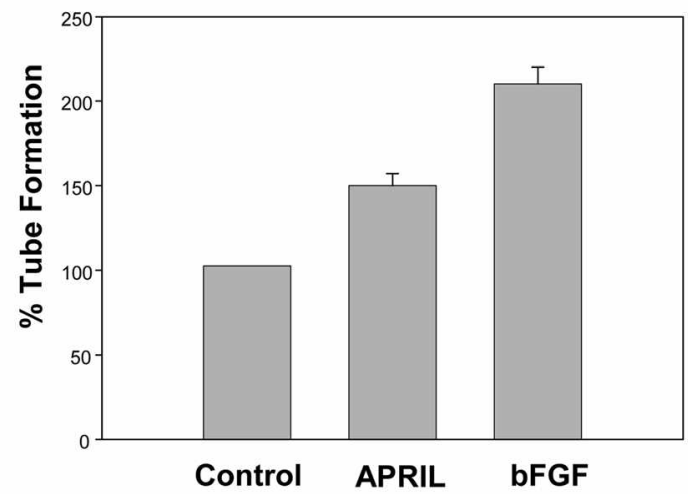

Figure 2. APRIL-CM promotes tube formation of endothelial cells. (A) HUVECs were collected and seeded on Matrigel-coated plates at a density of $2.4 \times 10^{4}$ cells/well and then incubated with control-CM or APRIL-CM. As a positive control, bFGF (10 ng/ min) was used. After $18 \mathrm{~h}$, fields from each sample were photographed. Representative inages of tube fomation activity are shown. (B) Total tube areas were analyzed and quantitated by the Scion Innage program. The control tube areas were defuned as $100 \%$ tube fonmation, and the percent increase in tube formation as compared with control was calculated for each sample.

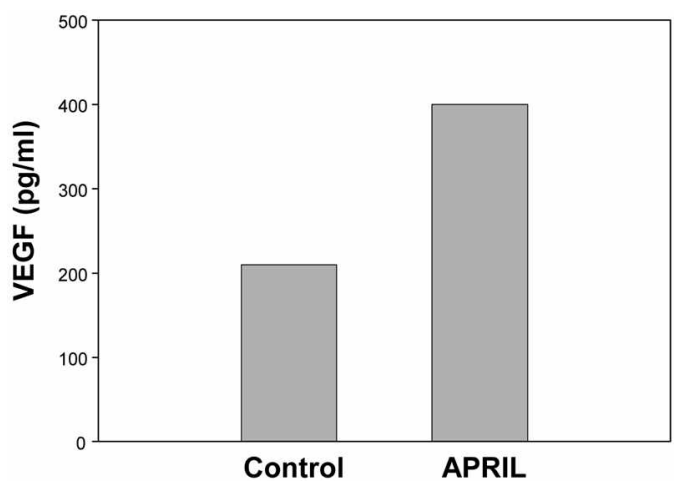

Figure 3. APRIL increases the level of VEGF in CM. Control or APRIL stable cells were incubated in serum-free M199 for $20 \mathrm{~h}$, and aliquots of the CM were collected. The level of VEGF in CM was measured by ELISA as described in experimental section.

$\kappa \mathrm{B}$. NF- $\kappa \mathrm{B}$ pathway is a physiological regulator of VEGF expression. ${ }^{7}$ APRIL-overexpressing cells were transfected with pNF- $\kappa$ B-Luc reporter plasnid and grown under normoxic condition. As shown in Figure 4, APRIL-overexpressing cells resulted in an increase of the luciferase activity. Interestingly, transcriptional activity of HIF-l $\alpha$ that is stabilized at hy poxia and plays a key role in VEGF transcription was not affected by APRIL irrespective of oxygen level (data not shown). Thus this result demonstrates that APRIL

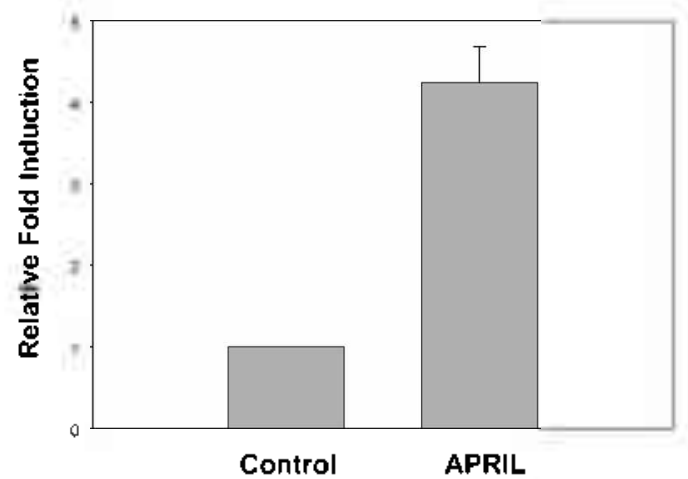

Figure 4. APRIL activates the transactivation function of $\mathrm{NF}-k \mathrm{~B}$. HEK 293 cells that constitutively express APRIL and control cells that contain empty plasmid were transfected by lipofectamine with $1 \mathrm{tg}$ each of the reporter plasmid $\mathrm{pNF}-\mathrm{AB}-\mathrm{Luc}$ and $0.5 \mathrm{tg}$ of $\mathrm{pCMV} / \beta$ gal. Luciferase activities were nomalized to $\beta$ galactosidase activities.

activates not HIF-l $\alpha$ but NF- $\mathrm{kB}$ transcriptional activity.

In this study, we examined whether APRIL has angiogenic activity by using several assays. First. we tested endothelial cell migration and tube formation of HUVEC. We can expect that APRIL may affect vascular signaling directly or indirectly. Next. we confirmed that APRIL induced the NF$k \mathrm{~B}$ transcriptional activity. leading to increase of VEGF secretion. These fundings support the notion that neovascularization and progression of HCC may be induced by APRIL via VEGF expression. ${ }^{\text {it }}$

In conclusion. we demonstrated that APRIL mediates angiogenesis and VEGF might be the target of APRIL-mediated process. APRIL might be a candidate for developing anti-cancer agent in tumor growth and angiogenesis.

\section{Experimental Section}

Cell culture. Human embryonic kidney (HEK) 293 and HUVECs were routinely maintained as previously described. $^{19}$

Plasmid constructs. The $N$-terminal hemagglutinin (HA)tagged human APRIL gene for expression in mammalian cells was constructed by polymerase chain reaction. followed by cloning into the pcDNA3.1/Zeo plasnid.

Transfection and selection of transfected cells. HEK 293 cells were transfected by lipofectamine (Invitrogen) with $1 \mu \mathrm{g} / \mathrm{mL}$ each of pcDNA3.1/Zeo-HA-APRIL or pcDNA3.1/Zeo-empty vector as a control. After $48 \mathrm{~h}$, transfected cells were selected for two weeks in DMEM containing $10 \%$ FBS and Zeocin $(200 \mu \mathrm{g} / \mathrm{mL})$. After 15 days of selection. resistant cells arising in dishes were propagated in low level ( $150 \mu \mathrm{g} / \mathrm{mL}$ ) of Zeocin. The overexpressed APRIL in stably transfected cells was confirmed by inmmunoblotting.

Immunoblotting. Cells were lysed in a buffer solution containing $20 \mathrm{mM}$ Tris- $\mathrm{HCl}$ (pH 7.5). $150 \mathrm{mM} \mathrm{NaCl} .5 \mathrm{mM}$ EDTA, $10 \mathrm{mM} \mathrm{NaF} .1 \%$ Triton $\mathrm{X}-100.0 .5 \%$ deoxycholate. $1 \mathrm{mM}$ DTT. $1 \mathrm{mM}$ sodium orthovanadate. $1 \mathrm{mM} \mathrm{PMSF}$, and $1 \mathrm{~kg} / \mathrm{mL}$ aprotinin for $30 \mathrm{~min}$ at $4{ }^{\circ} \mathrm{C}$. followed by centri- 
fugation at $13,000 \mathrm{rpm}$ for $30 \mathrm{~min}$. Cell lysates were run in SDS-PAGE and transferred to nitrocellulose membrane. The blocked membrane was then incubated with an anti-HA antibody, followed by an appropriate secondary antibody conjugated to horseradish peroxidase. The inmunoreactive bands were visualized using an ECL system.

APRIL-CM preparation. Confluent cells were washed and grown in serum free M199 medium. After $20 \mathrm{~h}$ of incubation. CM was collected and centrifuged at $500 \times \mathrm{g}$ for $10 \mathrm{~min}$ and then at $800 \times \mathrm{g}$ for $20 \mathrm{~min}$ to remove debris. The resultant $\mathrm{CM}$ was immediately used for migration and tube formation assays or stored at $-70^{\circ} \mathrm{C}$ until use

HUVEC migration and tube formation assays. Endothelial cell migration and tube formation assays were carried out as previously described.

Determination of the VEGF level. To determine the VEGF protein expression level. we obtained CM from control or stable cells. The amount of VEGF in the CM from the cells was deternined as previously described. ${ }^{10}$

Luciferase assays. Transfected cells were grown to 50 $70 \%$ confluence in $60 \mathrm{~mm}$ dish. and were transfected by lipofectanine (Invitrogen) with $1 \mu \mathrm{g}$ reporter plasnid pNF$\kappa \mathrm{B}-\mathrm{Luc}$ and $0.5 \mu \mathrm{g}$ of $\mathrm{pCMV} / \beta$ gal and assayed as previously described. ${ }^{21}$

Capillary-like tube formation assays. Tube formation assays were performed as previously described. ${ }^{23}$

Acknowledgments. We thank Sewook Hwang for technical assistance in tube formation and migration assays. This work was supported by a grant of the Korea Health 21 R\&D Project. Munistry of Health \& Welfare. Republic of Korea (01-PJI0-PG6-01GN16-0005).

\section{References}

1. Boehm-Viswanathan. T. Cumr. Opin. Oncol. 2000. I2(1). 89-94

2. Carmeliet. P. Nat. Med. 2003, $9(6), 653-660$.

3. Carmeliet. P.: Jain. R. K. Nature 2000. 107(6801), 249-257.
4. Yoshiji. H.: Kuriyama. S.: Yoshii. J.: Ikenaka. Y: Noguchi. R.: Hicklin. D. J.: Huber. I.: Nakatani. T.: Tsujinoule. H.: Yanase. K.: Innazu. H.: Fukui. H. Hepatolog 2002. $35(4) .834-842$.

5. Fukuda. R.; Kelly. B.: Semenza, G. L. Cancer Res. 2003. 63(9) 2330-2334

6. Ravi. R.: Mookerjee. B.: Bhujwalla, Z. M.; Sutter. C. H.; Artemov. D.: Zeng. Q: Dillehay. L. E.: Madan. A.: Semenza. G. L.: Bedi. A Genes $D e\urcorner$ : 2000. $1+(1) .34-44$

7. Kiriakidis. S.: Andreakos. E.: Monaco. C.: Fowwell. B.: Feldmarun. M: Paleolog, E. d. Cell Sci. 2003, $116(\mathrm{Pt} 4) .665-674$

8. Khare, S. D.: Hsu. H. Trends. Immmol. 2001. 22(2), 61-63.

9. Smith. C. A.; Farrah. T:; Goodwin, R. G. Cell 1994. 76(6). 959962

10. Hahne. M.: Kataoka. T:: Schroter. M.: Hofmant1. K.: Irmler. M. Bodmer. T. L.: Schneider. P.: Bornand. T.: Holler. N.: French. L. E.; Sordat. B.: Rimoldi, D; Tschopp. J. J. Exp. Hed. 1998. 188(6). $1185-1190$.

11. Kelly, K.: Manos, E.: Jensen, G: Nadauld. L; Jones. D. A Concer Res. 2000. 60(4). 1021-1027

12. Ware. C. F. J. Exp. Med 2000. $192(11) . \mathrm{F} 35-\mathrm{F} 38$

13. Yu. G.: Boone. T.: Delaney. T.: Hawkins. N.: Kelley. M.: Ramakrishnan, M.; McCabe, S.; Qiu. W. R.: Kornue, M.; Xia, X. Z.; Guo. J.: Stolina. M.: Boyle, W. J.: Sarosi, I.: Hsu. H.; Senaldi. G.; Theill, L. E. Nat. Immmil. 2000. 1(3), 252-256.

14. Endo. T.: Nishio. M.: Enzler. T.: Cottam. H. B.: Fukuda. T.: James. D. F.: Karin. M.: Kipps. T. J. Blood 2007. $109(2)$. 703-710

15. Roth. W.: Wagenkinecht. B.: Klumpp. A.: Naumann. U.: Hahne. M:- Tschopp, J:- Weller, M. Cell Death Differ: 2001, 8(4), 403410 .

16. Litinskiv: M. B.: Nardelli. B.; Hilbert. D. M.: He, B.; Schaffer. A.; Casali. P.: Cerutti. A. Not. Intmunol. 2002. 3(9). 822-829.

17. Marsters. S. A.: Yan. M.: Pitti. R. M.: Haas. P. E.: Dixit. V. M. Ashlenazi. A. Curr Biol. 2000. 10(13). 785-788

18. Okano, H.; Shiraki, K.: Yamanaka. Y.: Inoue, H.: Kawakita, T. Saitou, Y; Yamaguchi, Y; Enokimura, N.: Ito. K.: Yamamoto, N. Sugimoto, K: Murata, K.: Nakano. T. Horld J. Gastroenterol. 2005. $H(30) .4650-4654$.

19. Cho. S. Bull. Korean Chem. Soc. 2005. 26. 1823-1825.

20. Song. M.: Cho. S. Bull. Korem Chem. Soc. 2007. 28(9). 16131614

21. Park, J. E; Lee, D. H.; Lee, J. A.; Park, S. G: Kim, N. S.: Park, B C. Cho, S. Biochem Biophys. Res. Commun 2005, 337(4). 12831287.

22. Song. M.: Cho. S. Bull. Korem Chem. Soc. 2007. 28(7). 12061208 . 